\title{
Economic Analysis of the Chemical Industry of the Czech Republic in the Period of Economic Growth
}

\author{
David VLCEK ${ }^{1}$ and Jana KOSTALOVA ${ }^{2}$ \\ 1 University of Pardubice, Pardubice, Czech Republic; david.vlcek@upce.cz \\ 2 University of Pardubice, Pardubice, Czech Republic; jana.kostalova@upce.cz \\ * Correspondence: david.vlcek@upce.cz
}

\begin{abstract}
The chemical industry accounts for less than $1 \%$ of the Czech Republic's industry, and this percentage has been decreasing due to the growth of other industries. Despite this, it has an important position, especially in terms of input producer for other areas of industry and agriculture. The percentage of employees and their wages in the chemical industry has been increasing recently. In the period of economic growth, the growth of the chemical industry has been recorded in all important indicators - value added, profit, sales and investment. Foreign trade in chemical products has a long-term negative balance in the Czech Republic. The article discusses the situation in the chemical industry of the Czech Republic over the last eight years from the economic point of view compared with the industry as a whole, the outputs of the financial analysis of the chemical industry compared with the manufacturing industry. There are also described the challenges and problems the chemical industry is currently facing. These include slowing economic growth, the emergence of new technologies known as Industry 4.0, the lack of workers in the labour market, the changing demands of workers and the increasing demands for accountability and sustainability of business activities.
\end{abstract}

Keywords: chemical industry; economic indicators; Czech Republic

JEL Classification: L65; O14

\section{Introduction}

The production of chemicals and chemical preparations is one of the most advanced industries in the Czech Republic (CZ). It has a long history and occupies a very important position in the economy of $\mathrm{CZ}$ since its products are used in all areas of the economy, especially in other sections of the manufacturing industry such as manufacture of plastics and rubber, textile industry, electronics industry, construction, pulp and paper industry and automotive industry. The chemical industry is a supplier of resources for many industries and is very closely linked to them (Ministry of Industry and Trade CZ 2019a).

According to the standard classification of economic activities CZ NACE, the chemical industry belongs to Section C - Manufacturing Industry, Division 20 Manufacture of chemicals and chemical products. This Division is divided into 6 groups:

- 20.1 Manufacture of basic chemicals, fertilisers and nitrogen compounds, plastics and synthetic rubber in primary forms;

- $\quad 20.2$ Manufacture of pesticides and other agrochemical products;

- $\quad 20.3$ Manufacture of paints, varnishes and similar coatings, printing ink and mastics;

- 20.4 Manufacture of soap and detergents, cleaning and polishing preparations, perfumes and toilet preparations;

- 20.5 Manufacture of other chemical products;

- 20.6 Manufacture of man-made fibres.

The CZ NACE 20 Chemical Industry division is also closely related to the CZ NACE 21 Pharmaceutical Industry, CZ NACE 22 Rubber and Plastics Industry and CZ NACE 19.2 Manufacture of refined petroleum products. In addition to chemical companies, the chemical industry is also assessed from the point of view of products, namely products of the chemical industry according to the standard 
classification of products CZ-CPA classified in Section C - Products and services of manufacturing industry, Division 20 Chemicals and chemical products, including subcontracting.

Of the above-mentioned groups, CZ 20.1 is the dominant group in the chemical industry, i.e. the basic petrochemical industry, manufacture of inorganic and organic chemicals and polymers. This group includes the ten largest chemical companies in CZ. Large enterprises clearly dominate in the CZ NACE 20 group; in 2017, they accounted for $67 \%$ of sales, $63 \%$ of value added and employed $54 \%$ of employees working in the chemical industry (Ministry of Industry and Trade CZ 2018)

The economic situation in the chemical industry is influenced by the development of the economy as a whole. In the last 15 years, after the economic growth until 2009, the economic crisis has been particularly important. The situation in the chemical industry until the end of 2010 was assessed by Kraus and Spicka (2013). As a result of the economic crisis, the chemical industry has seen a reduction in the number of employees, a decrease in return on equity and assets and minor fluctuations in the foreign trade balance and other indicators of financial analysis, but overall, the authors evaluate the development of the chemical industry in times of crisis positively as chemical industry companies managed to deal with the crisis relatively quickly and well.

The assessment of further development from the point of view of the Ministry of Industry and Trade of $\mathrm{CZ}$ and the Association of Chemical Industry is more or less positive. According to an analysis of the Ministry of Industry and Trade of CZ, sales development after the crisis year 2009 decreased to a minimum and then gradually started to increase until 2012. After that it decreased slightly again in 2013, followed by another period of sales growth until 2016. In 2017 and 2018, it is, in particular, increasing sales, the number of workers in the chemical industry and wage growth that are positively assessed, but this gradually decreases productivity growth year-on-year. It positively evaluates the increase in return on equity and risk reduction. It is already in this period a shortage of technically educated workers was identified. These analyses also highlight the decreasing interest in chemistry. Interest in workers with this qualification also started to increase in other related branches of the manufacturing industry. (Ministry of Industry and Trade CZ 2018; Ministry of Industry and Trade CZ 2019a; Association of Chemical Industry 2019a)

A similar course of development of the chemical industry can also be observed at European level. In 2009 , there was a significant drop in production by more than $20 \%$. However, production was resumed in the years to come, although the chemical industry in the European Union (EU) did not reach pre-crisis production levels until 2018. However, since 2015 it has been steadily increasing. Foreign trade in products of the chemical industry in the EU has a balance opposite to the one in $\mathrm{CZ}$, exports has long prevailed over imports. Also, in this area there was a decrease in 2009, more significantly in imports than in exports, but since 2010, both imports and exports have been increasing and, in both cases, they have already reached the pre-crisis levels in 2010. Consumption of chemical products in the domestic European market also declined in 2009, subsequently consumption started to grow until 2012, but unlike the foreign balance, which had a continuously rising character in consumption, there was a slight decline, peaking in 2016. In the subsequent period, consumption again increased to EUR 133 billion in the first quarter of 2019. (Cefic 2019) The chemical industry at EU level provides 1.14 million jobs with 28,330 companies operating within it (Ministry of Industry and Trade CZ 2019a). Within the European Union, it is Germany (28.6\%), France (13.6 \%), Italy (9.8 \%), the Netherlands (9.6\%), Belgium (7.3\%), Spain (7.2 $\%)$, United Kingdom (6.7\%) that have the largest share of production. The rest of the EU accounts for $17.2 \%$ of production, and as a whole, the chemical industry ranks the fourth in the EU with the highest turnover. Labour productivity in the EU chemicals industry is by 77 \% higher than the EU manufacturing industry average and has been rising over a long period. Investments in the chemical industry are also growing; in 2015, the chemical industry was the largest investor in the manufacturing industry, with investments amounting to EUR 45.5 billion, outperforming the automotive industry. On the other hand, the overall share of the EU chemicals industry in total GDP is only $1.1 \%$ (Cefic 2018). Workforce in the EU chemical industry is more skilled, educated and better paid, with wages $50 \%$ higher than the EU manufacturing industry average (Association of Chemical Industry 2019a).

Globally, the chemical industry noted a turnover of EUR 3,475 billion in 2017 versus EUR 3,360 billion in 2016 in the period of growth. The global market is expected to double by 2030. Worldwide, China ranks first with EUR 1,293 billion in turnover, followed by the EU with EUR 542 billion and 
NAFTA (North American Free Trade Agreement) with EUR 519 billion (Ministry of Industry and Trade CZ 2018; Ministry of Industry and Trade CZ 2019a).

The aim of the article is to analyse the current situation of the chemical industry in $C Z$ to the extent corresponding to the classification of economic activities of CZ NACE 20 in the basic parameters of economic and financial analysis and, based on the observed trends, to identify the current challenges and problems the chemical industry is facing today and in the future or can take advantage of.

\section{Methodology}

The article includes analysis of statistical data at national level. From the producers' point of view, the data taken into consideration relate to CZ NACE 20; from the product point of view, they relate to CZ CPA 20. The period under review is based on the availability of data from 2010 to 2018, whereas data for 2018 is based on Ministry of Industry and Trade CZ estimates only. At the same time, primary data were collected through participation in conferences in the chemical industry, round tables with personnel managers of the chemical industry, study of analysis and studies in the chemical industry. Based on the synthesis of obtained information, the outputs of the article were processed.

\section{Results}

\subsection{Chemical industry CZ NACE 20 until 2019}

In the period under consideration 2010 to 2018, as can be seen from Table 1, there were between 1742 and 1851 entities operating in the chemical industry, corresponding to less than $1 \%$ of all entities operating in industry. This percentage has been declining, even though the total number of entities in the chemical industry varies. This can be seen as a consequence of the growing total number of entities in the industry.

Table 1. Number of entities in the CZ-NACE 20 and its share in industry

\begin{tabular}{cccccccccc}
\hline Year & $\mathbf{2 0 1 0}$ & $\mathbf{2 0 1 1}$ & $\mathbf{2 0 1 2}$ & $\mathbf{2 0 1 3}$ & $\mathbf{2 0 1 4}$ & $\mathbf{2 0 1 5}$ & $\mathbf{2 0 1 6}$ & $\mathbf{2 0 1 7}$ & $\mathbf{2 0 1 8}$ \\
\hline $\begin{array}{c}\text { Number of entities in } \\
\text { the CZ-NACE 20 }\end{array}$ & 1,742 & 1,819 & 1,837 & 1,765 & 1,761 & 1,762 & 1,754 & 1,793 & 1,851 \\
Share in industry & $0.98 \%$ & $0.99 \%$ & $0.98 \%$ & $0.97 \%$ & $0.94 \%$ & $0.93 \%$ & $0.92 \%$ & $0.92 \%$ & NA \\
\hline
\end{tabular}

Source: (original authors' calculation, Czech Statistical Office 2019a, Ministry of Industry and Trade CZ 2019b)

In addition to changes in the number of entities operating in the chemical industry, the number of persons employed also changed in the period under review. The development of the number of persons employed and the percentage of all persons employed in industry is shown in Table 2.

Table 2. Number of employees in the chemical industry at the end of the fourth quarter of each year and their percentage in industry

\begin{tabular}{cccccccccc}
\hline Year & $\mathbf{2 0 1 0}$ & $\mathbf{2 0 1 1}$ & $\mathbf{2 0 1 2}$ & $\mathbf{2 0 1 3}$ & $\mathbf{2 0 1 4}$ & $\mathbf{2 0 1 5}$ & $\mathbf{2 0 1 6}$ & $\mathbf{2 0 1 7}$ & $\mathbf{2 0 1 8}$ \\
\hline $\begin{array}{c}\text { Number of employees } \\
\text { in the CZ-NACE 20 }\end{array}$ & 29,583 & 29,011 & 28,906 & 28,805 & 29,321 & 30,171 & 30,856 & 31,676 & 32,979 \\
$\begin{array}{c}\text { Share of number of persons } \\
\text { employed in industry }\end{array}$ & $2.3 \%$ & $2.2 \%$ & $2.2 \%$ & $2.3 \%$ & $2.2 \%$ & $2.2 \%$ & $2.3 \%$ & $2.3 \%$ & $2.4 \%$ \\
\hline
\end{tabular}

Source: (original authors' calculation, Czech Statistical Office 2019b)

While the percentage of employees in the chemical industry in the number of all the employed did not change substantially, the total number of persons employed in the chemical industry increased, especially in the final years. However, wage growth was much more significant. Wages increased by a quarter from CZK 26,240 to CZK 32,666 between 2010 and 2017. As can be seen from Figure 1, they did not reach the level of wages in the automotive industry, which is the driving force of the Czech economy, but they were above average in industry (see Figure 1). 


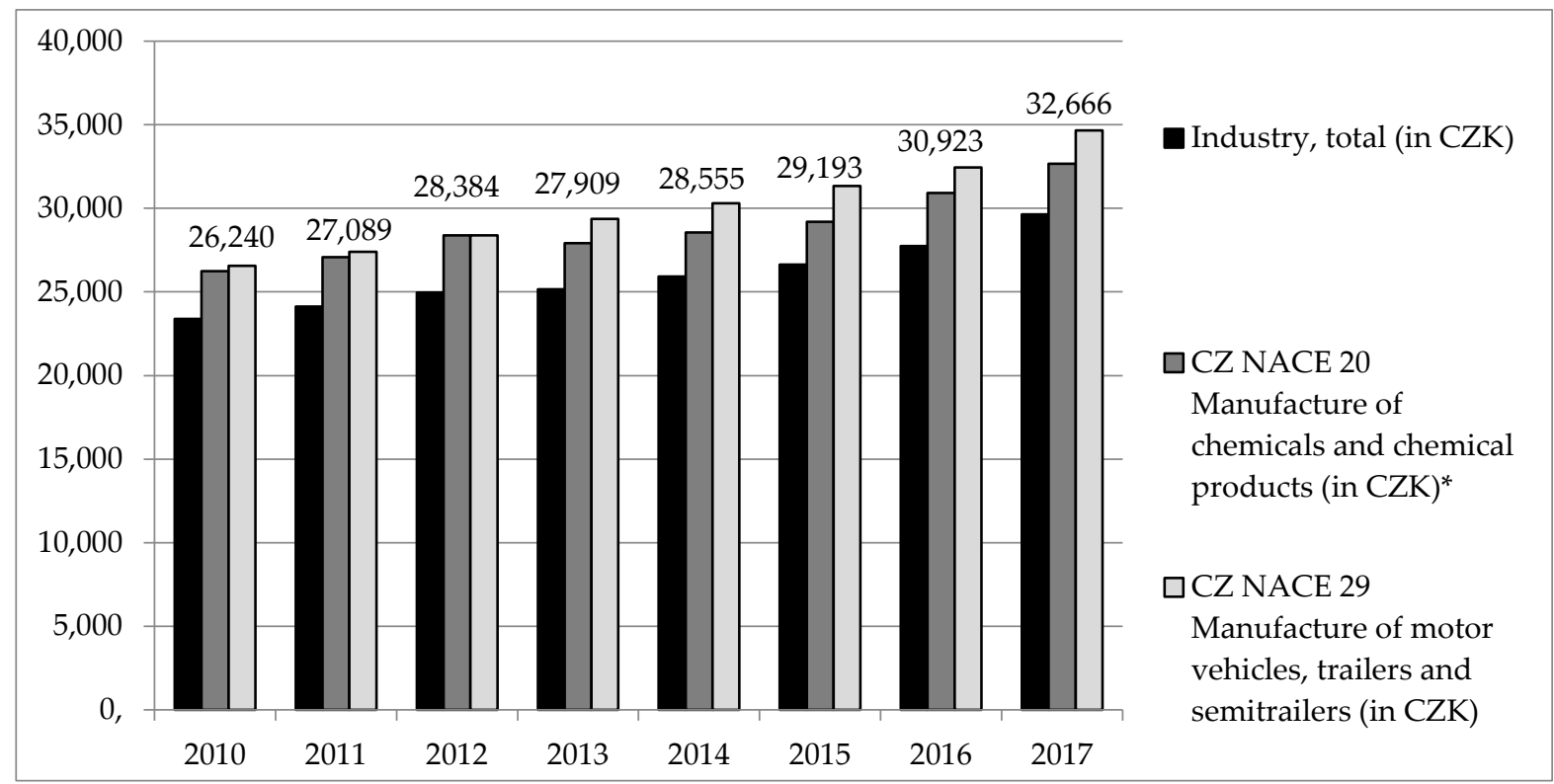

Figure 1. Comparison of wages in chemical industry, automotive industry and industry as whole (Czech Statistical Office 2019a)

* presented numbers are wages in CZ NACE 20 Manufacture of chemicals and chemical products

If we look at the development of the chemical industry in terms of economic benefits (Table 3), namely sales, value added and profit, we find that all of these indicators saw a significant increase in their value.

Table 3. Selected economic indicators of chemical industry

\begin{tabular}{|c|c|c|c|c|c|c|c|c|c|}
\hline Year & 2010 & 2011 & 2012 & 2013 & 2014 & 2015 & 2016 & 2017 & 2018 \\
\hline $\begin{array}{c}\text { Value added } \\
\text { (millions of CZK) } \\
\text { After-tax }\end{array}$ & 30,584 & 31,808 & 31,616 & 28,774 & 36,638 & 41,967 & 34,104 & 49,996 & 51,367 \\
\hline $\begin{array}{c}\text { Profit/Loss } \\
\text { (millions of CZK) } \\
\text { Sales }\end{array}$ & 8,900 & 6,177 & 9,115 & 6,594 & 11,143 & 16,474 & 15,142 & 22,655 & 17,759 \\
\hline (millions of CZK) & 152,791 & 169,835 & 178,624 & 171,577 & 186,573 & 171,392 & 165,843 & 191,745 & 274,797 \\
\hline $\begin{array}{c}\text { Industry Added } \\
\text { Value Share }\end{array}$ & $3.2 \%$ & $3.2 \%$ & $3.1 \%$ & $2.8 \%$ & $3.2 \%$ & $3.6 \%$ & $2.8 \%$ & $4.0 \%$ & NA \\
\hline $\begin{array}{l}\text { Industry After-tax } \\
\text { Profit/Loss Share }\end{array}$ & $3.5 \%$ & $2.3 \%$ & $2.8 \%$ & $2.3 \%$ & $3.7 \%$ & $5.0 \%$ & $4.9 \%$ & $7.0 \%$ & NA \\
\hline $\begin{array}{c}\text { Industry Sales } \\
\text { Share }\end{array}$ & $3.4 \%$ & $3.5 \%$ & $3.5 \%$ & $3.3 \%$ & $3.5 \%$ & $3.1 \%$ & $3.0 \%$ & $3.2 \%$ & NA \\
\hline
\end{tabular}

Source: (original authors' calculation, Czech Statistical Office 2019a, Ministry of Industry and Trade CZ 2019b)

However, this increase was accompanied by two significant declines in 2013 and 2016. With the increasing value of these indicators, with the exception of sales, their share in industry increased (see Table 3).

Increasing sales and profits were also reflected in investments. Investments increased at a time of rising profits and conversely, when profits fell, so did the amount of invested funds. In both indicators (profit/loss, investments), there is generally an increasing trend in the period under review. Along with investments, there was also a steady increase in the assets of chemical enterprises in the period under review (see Table 4). In terms of the ratio of assets and investments to the industry as a whole, there is a decline between 2010 and 2014, followed by a relatively fast increase. 
Table 4. Net assets and investments of chemical industry and their share in industry in total

\begin{tabular}{|c|c|c|c|c|c|c|c|c|c|}
\hline Year & 2010 & 2011 & 2012 & 2013 & 2014 & 2015 & 2016 & 2017 & 2018 \\
\hline $\begin{array}{c}\text { Net assets } \\
\text { (millions of CZK) }\end{array}$ & 146,209 & 149,841 & 150,681 & 151,435 & 152,342 & 154,711 & 171,483 & 188,126 & 202,358 \\
\hline $\begin{array}{c}\text { Investments } \\
\text { (millions of CZK) }\end{array}$ & 8,232 & 6,983 & 6,256 & 7,449 & 7,315 & 11,468 & 14,371 & 14,237 & 12,628 \\
\hline $\begin{array}{l}\text { Industry net } \\
\text { assets share }\end{array}$ & $3.4 \%$ & $3.4 \%$ & $3.4 \%$ & $3.3 \%$ & $3.2 \%$ & $3.2 \%$ & $3.5 \%$ & $3.7 \%$ & NA \\
\hline $\begin{array}{c}\text { Industry } \\
\text { investments share }\end{array}$ & $3.1 \%$ & $2.6 \%$ & $2.3 \%$ & $2.8 \%$ & $2.6 \%$ & $3.9 \%$ & $5.1 \%$ & $4.4 \%$ & NA \\
\hline
\end{tabular}

Source: (original authors' calculation, Czech Statistical Office 2019a, Ministry of Industry and Trade CZ 2019b)

CZ is generally an exporter rather than an importer. In the field of chemical products, however, the opposite is true and imports of these products prevail.

Table 5. Export and import of chemical industry products (CZ-CPA 20) from the national point of view

\begin{tabular}{cccccccccc}
\hline Year & $\mathbf{2 0 1 0}$ & $\mathbf{2 0 1 1}$ & $\mathbf{2 0 1 2}$ & $\mathbf{2 0 1 3}$ & $\mathbf{2 0 1 4}$ & $\mathbf{2 0 1 5}$ & $\mathbf{2 0 1 6}$ & $\mathbf{2 0 1 7}$ & $\mathbf{2 0 1 7}$ \\
\hline Import (billion CZK) & 117.5 & 136.9 & 146.5 & 152.1 & 166.9 & 150.3 & 140.8 & 160.5 & 160.5 \\
Export (billion CZK) & 171.1 & 202.8 & 213.6 & 226.2 & 252.2 & 254.7 & 260.3 & 270.0 & 270.0 \\
Balance (billion CZK) & -53.6 & -65.9 & -67.1 & -74.1 & -85.3 & -104.4 & -119.5 & -109.5 & -109.5 \\
\hline
\end{tabular}

Source: (Czech Statistical Office 2019c)

As can be seen from Table 5, which shows the import and export of chemical products in the national concept, the import of chemical products prevailed over their export in all the monitored years. Moreover, this difference (balance) increases (except for 2017) from year to year. Despite the fact that exports increased by more than a third between 2010 and 2017. This difference is mainly due to the fall in exports in 2015 and 2016.

Table 6. Share of exports and imports of chemical products (CZ-CPA 20) in the total exports and imports of $\mathrm{CZ}$ from the national point of view

\begin{tabular}{ccccccccc}
\hline Year & $\mathbf{2 0 1 0}$ & $\mathbf{2 0 1 1}$ & $\mathbf{2 0 1 2}$ & $\mathbf{2 0 1 3}$ & $\mathbf{2 0 1 4}$ & $\mathbf{2 0 1 5}$ & $\mathbf{2 0 1 6}$ & $\mathbf{2 0 1 7}$ \\
\hline $\begin{array}{c}\text { Share of exports of chemical } \\
\text { products in total exports of CZ }\end{array}$ & $5.0 \%$ & $5.3 \%$ & $5.4 \%$ & $5.5 \%$ & $5.3 \%$ & $4.6 \%$ & $4.3 \%$ & $4.6 \%$ \\
$\begin{array}{c}\text { Share of imports of chemical products } \\
\text { in total imports of CZ }\end{array}$ & $7.3 \%$ & $7.9 \%$ & $8.0 \%$ & $8.4 \%$ & $8.4 \%$ & $8.1 \%$ & $8.3 \%$ & $8.1 \%$ \\
\hline
\end{tabular}

Source: (original authors' calculation, Czech Statistical Office 2019c)

From the nationwide trade balance point of view, exports of chemical products grew faster than total exports of CZ until 2013 (a drop in the share in total exports). Since then, the growth was slower (up to 2017). As can be seen from Table 6, imports of chemical products make up around $8 \%$ of all imports to CZ.

\subsection{Financial analysis of chemical industry in the Czech Republic}

Four indicators (ROE, Net turnover/Assets, Liquidity L3 and Interest-bearing resources (IBR)/Assets) from the INFA methodology used by the Ministry of Industry and Trade of CZ for financial analysis were selected for the financial analysis of the chemical industry. The values and development of these indicators in chemical enterprises were subsequently compared with the results 
for the manufacturing industry of which the chemical industry is a part. ROE (Return on Equity) was used as profitability indicator calculated as (Ministry of Industry and Trade CZ 2019c):

$$
\text { ROE }=\text { Profit/Loss for the accounting period / Equity }
$$

This indicator tells us what profit the company generates from CZK 1 of its equity. The values of this indicator for the chemical and manufacturing industries are shown in Table 7. This shows a greater volatility in the profitability of chemical enterprises. While manufacturing industry values ranged from $12 \%$ to $17 \%$, chemical industry values ranged from $8.92 \%$ (2011) to $21.03 \%$ (year 2015).

Table 7. Selected financial indicators of the chemical and manufacturing industries

\begin{tabular}{cccccccccc}
\hline Year & $\mathbf{2 0 1 0}$ & $\mathbf{2 0 1 1}$ & $\mathbf{2 0 1 2}$ & $\mathbf{2 0 1 3}$ & $\mathbf{2 0 1 4}$ & $\mathbf{2 0 1 5}$ & $\mathbf{2 0 1 6}$ & $\mathbf{2 0 1 7}$ & $\mathbf{2 0 1 8}$ \\
\hline $\begin{array}{c}\text { ROE CZ-NACE 20 } \\
\text { ROE manufacturing } \\
\text { industry }\end{array}$ & $12.4 \%$ & $8.9 \%$ & $12.6 \%$ & $9.7 \%$ & $16.5 \%$ & $21.0 \%$ & $16.1 \%$ & $20.4 \%$ & $14.5 \%$ \\
$\begin{array}{c}\text { Net turnover/Assets } \\
\text { CZ-NACE 20 }\end{array}$ & 1.15 & 1.23 & 1.37 & 1.27 & 1.35 & 1.21 & 1.12 & 1.11 & 1.43 \\
$\begin{array}{c}\text { Net turnover/Assets } \\
\text { manufacturing } \\
\quad \text { industry }\end{array}$ & 1.41 & 1.45 & 1.48 & 1.43 & 1.48 & 1.51 & 1.42 & 1.46 & 1.52 \\
$\quad \begin{array}{l}\text { IBS/ Assets } \\
\text { CZ-NACE 20 }\end{array}$ & $60.3 \%$ & $57.3 \%$ & $59.1 \%$ & $55.0 \%$ & $55.2 \%$ & $60.7 \%$ & $60.0 \%$ & $63.7 \%$ & $65.1 \%$ \\
$\quad \begin{array}{l}\text { IBS/Assets } \\
\text { manufacturing } \\
\text { industry }\end{array}$ & $58.7 \%$ & $57.6 \%$ & $59.3 \%$ & $58.7 \%$ & $58.9 \%$ & $59.9 \%$ & $59.2 \%$ & $58.3 \%$ & $60.3 \%$ \\
$\begin{array}{c}\text { L3 CZ-NACE 20 } \\
\text { L3 manufacturing } \\
\text { industry }\end{array}$ & 1.28 & 1.28 & 1.3 & 1.25 & 1.33 & 1.49 & 1.42 & 1.62 & 1.51 \\
\hline
\end{tabular}

Source: (Ministry of Industry and Trade CZ 2019b)

Net turnover/assets were used as an indicator of turnover. As can be seen from Table 7. Thus, in all the years under review, turnover was higher in manufacturing industry as a whole than that in chemical enterprises.

The interest-bearing resources (IBS)/Assets ratio was used to assess the indebtedness. It tells us what part of the assets is financed from interest-bearing resources. In the case of indebtedness, as in the case of turnover, there is a markedly greater volatility in chemical enterprises. In addition, Table 7 shows that after the decline in the indebtedness of chemical enterprises below $60 \%$ between 2011 and 2014, it rose to $65.09 \%$ in 2018.

The last indicator used is the liquidity indicator L3. It is constructed as (Ministry of Industry and Trade CZ 2019c):

$$
\text { Liquidity L3 = Current Assets / (Short-term Liabilities + Short-term Bank Loans) }
$$

This liquidity indicator shows how many times current assets exceed short-term liabilities and shortterm loans. Both in the chemical industry and in the manufacturing sector, a gradual increase in liquidity can be observed with some exceptions. It is faster in chemical enterprises, where this indicator was generally lower.

\subsection{Challenges and problems of the chemical industry in the Czech Republic}

Based on the collection of data from literature, studies by professional associations and consulting firms, statistical data, scientific and industry conferences and meetings in chemical industry enterprises, the challenges and problems that the chemical industry is facing in the present and near future have been identified: 
- Economic development (slowdown of economic growth) and growth of world competition;

- IT development mainly Industry 4.0 and its use in the chemical industry;

- Raising sustainability requirements for business activities and environmental protection;

- Research, development and innovation;

- Trends in production (changes of raw material costs, product portfolio and the market situation)

- Labour market situation, demographic trends, labour shortages, pressure on wage growth and the young generation's approach to participation in the work process;

- Education;

o Chemical and related fields in the education system in CZ;

o Training of workers in the chemical industry.

On the one hand, these challenges and problems brings high investment demands (deployment of Industry 4.0 technologies, reducing energy and waste, changing technologies to increase sustainability and establish a circular economy), on the other hand, they can provide solutions to these problems - the onset of robotization can, in certain areas, eliminate problems related to the lack of job applicants in the labour market, reduce input material costs, optimize energy consumption, etc.

There are a number of good practice examples in all the above areas. The leader in the implementation of Industry 4.0 in the chemical industry in CZ is the company Rakona of Procter \& Gamble, which intensively deals with new solutions for automated production lines and tries to introduce Industry 4.0 elements into the management of the entire business. As a result of these changes, the company has ranked among the TOP 9 companies best prepared for the upcoming changes related to Industry 4.0 (World Economic Forum 2018).

\section{Economic development}

Both $\mathrm{CZ}$ and neighbouring countries have been experiencing strong economic growth for several years. However, current indicators and forecasts suggest that this growth is hitting its limits in demand, limited labour force and is beginning to slow down. The problem for the Czech market is mainly the slowdown of the German economy, whose development is important for Czech exports. Germany is also a dominant partner for the chemical industry, both in terms of exports and imports. Exports to Germany accounted for $22 \%$ in 2017 and $21 \%$ in 2018 (Ministry of Industry and Trade CZ 2018, Ministry of Industry and Trade CZ 2019a). Potential trade barriers in the form of tariffs or the intensification of trade relations between America, especially the USA, China and the EU could also be a problem for the future. Brexit is also a potential danger for the Czech economy and the chemical industry, which can also destabilize the economic situation on the continent. Brexit is already causing uncertainty about its final form and deadline. Further political developments in the case of the conflict of interests of Prime Minister Andrej Babis may also cause problems for a significant part of the chemical industry of CZ.

However, assuming even a modest growth in manufacturing in the EU, a stable situation can also be expected in the chemical industry. Globally, EU sales are growing, but its world market share is gradually declining to the benefit China. The reason is massive investment in the region and high competition on world markets. Strict safety conditions (protection of workers' and consumers' health and environmental protection), pressure to reduce energy intensity, more efficient use of resources and the introduction of environmentally friendly technologies also play a significant role in the EU chemical industry. (Ministry of Industry and Trade CZ 2019a).

\section{IT development mainly Industry 4.0}

Industry 4.0 is the term for the fourth industrial revolution. Industry 4.0 is based on industrial IT integration, which is associated with real-time or near-real-time data processing, information sharing and continuous communication. The basic elements and procedures included to Industry 4.0 are usually integration, automation, digitalization and related terms digital factory and digital twins, robotization, cyber-physical systems, internet of thinks, internet of services, internet of people, virtual and augmented reality, additive production in form of 3D print, cloud computing, big data and 
business intelligence, machine learning systems, artificial intelligence and technology blokchain (Marik et al. 2016).

The use of Industry 4.0 elements in the chemical industry is very wide. Deloitte (2016) assumes it could be generally applicable practices, such as supporting business or economic operations to increase productivity, building smart factories, streamlining supply chains and improving the performance of existing assets. The use of Industry 4.0 elements directly in chemical industry technologies is called Chemistry 4.0 or Chemicals 4.0. Due to the high investment intensity of the introduction of new technologies, a rather gradual start is expected (Wehberg 2015). In the chemical industry there is expected to utilize Industry 4.0 tools for infrastructure maintenance and predictive maintenance management (internet of thinks, monitoring of technologies, monitoring data analysis etc.) to reduce energy consumption, reduce waste, reduce maintenance costs and reduce risks. It is also expected to use digital twins in the form of digital images of technologies, products, manufacturing processes that can be modified, optimized, monitored using data models, but also used for simulations during training. As volumes of collected production data increase, intensive use of data analysis, artificial intelligence and self-decision algorithms is expected (Palisek 2018; Deloitte 2016; Gilchrist 2016).

An expected benefit will also be in the elimination of routine, dangerous or health-threatening or strenuous activities. Demand for less and highly skilled workers is expected to increase, which can bring about labour market polarization and wage differentiation (National Observatory of Employment and Training, National Training Fund 2017)

\section{Increasing sustainability requirements for business activities and environmental protection}

At EU level, the long-term priorities include environmental protection, the effort of sustainable development and the reduction of climate change. Within the chemical industry, the EU has achieved a significant reduction in greenhouse gas production since 1996. Similarly, production of other substances affecting the environment has been reduced (Cefic 2018). At European level, Member States are thus succeeding in increasing production while reducing emissions. This support is based on European legislation, which gradually reflects the EU's international environmental commitments (e.g. $\mathrm{REACH}$ regulation). However, this positive trend also entails higher investment demands and, in comparison with world producers, mainly from China, it increases costs and thus reduces competitiveness.

In addition to the environmental legislative framework at European and national level (Tetrevova et al., 2017), there are also voluntary activities promoting responsible corporate behaviour in the environmental field. Responsible Care is a voluntary activity focused on sustainable development and social responsibility in the chemical industry. Established in 1986 in Canada, this activity brings together 64 national associations and over 200 global chemical companies. At present, there are 79 member organizations of the Association of Chemical Industry of CZ (Association of Chemical Industry of CZ 2019a; Association of Chemical Industry of CZ 2019b) that adhere to these commitments. Furthermore, there is the Association of Corporate Social Responsibility, which seeks to increase competencies in the area of corporate social responsibility and promote sustainable development policy, the Business Leader Forum, which supports responsible business environment, the Zeleny kruh association and many other organizations working in CZ (Association of Corporate Social Responsibility CZ 2019; Business Leader Forum 2019; Zeleny kruh 2019).

The demand for sustainability is reflected in the scope of innovation and investment; in this area we can find research and focus especially at the European level on circular economy and waste-free economy, efficient use of resources, searching for new energy sources, reducing energy intensity etc. However, the focus of sustainability in the chemical industry is directed not only to technology but also to the social dimension of sustainability. For more information see (Cefic 2017).

\section{Research, development and innovation}

Research, development and innovation in the chemical industry are funded from two basic sources - business sources (accounting for the majority of sources of financing) and public sources, 
either national or foreign. Research and development were carried out by 85 to 100 companies between 2010 and 2017 and their number increased steadily. Table 8 gives an overview of the volume of funds invested in research and development between 2010 and 2017.

Table 8. Expenditure on research and development in the chemical industry of CZ

\begin{tabular}{ccccccccc}
\hline Year & $\mathbf{2 0 1 0}$ & $\mathbf{2 0 1 1}$ & $\mathbf{2 0 1 2}$ & $\mathbf{2 0 1 3}$ & $\mathbf{2 0 1 4}$ & $\mathbf{2 0 1 5}$ & $\mathbf{2 0 1 6}$ & $\mathbf{2 0 1 7}$ \\
\hline $\begin{array}{c}\text { Volume of business sources } \\
\quad \text { (millions of CZK) }\end{array}$ & 808 & 820 & 856 & 982 & 1,059 & 1,027 & 836 & 1,021 \\
$\begin{array}{c}\text { Volume of national public sources } \\
\text { (millions of CZK) }\end{array}$ & 99 & 79 & 87 & 90 & 78 & 84 & 47 & 51 \\
$\begin{array}{c}\text { Volume of foreign public sources } \\
\text { (millions of CZK) }\end{array}$ & 56 & 112 & 15 & 55 & 47 & 55 & 23 & 29 \\
$\begin{array}{c}\text { Total (millions of CZK) } \\
\text { (m) }\end{array}$ & 962 & 1,011 & 958 & 1,127 & 1,183 & 1,166 & 906 & 1,101 \\
\hline
\end{tabular}

Source: (Ministry of Industry and Trade CZ 2019a)

At the level of national public sources, most often used are programmes of the Ministry of Industry and Trade of CZ (IMPULS, TIP, TRIO) and Technology Agency of CZ (Alfa, Centra kompetence, Delta, Epsilon, Zéta), Ministry of Defence (Development of Operational Capabilities of Armed Forces of CZ), Ministry of Education and Physical Education of CZ (EUREKA CZ), Ministry of the Interior of CZ (Security Research CZ 2015-2022, Security Research Programme of CZ 2010-2015), Ministry of Agriculture of CZ (VAK, KUS, ZEMĚ). Within the Operational Programs of the European Funds, 120 projects from the Operational Programme Enterprise and Innovation for Competitiveness directed to the chemical industry CZ_NACE 20 were approved between 2015 and October 2018 with the total planned support of CZK 1.72 billion, of which CZK 0.77 billion came from the EU funds. The focus of the projects is mainly on strengthening research and development capacities and introducing business innovations, cooperation of research institutions and enterprises. Chemical industry enterprises are also involved in projects at EU level, 4 companies participate in Horizon 2020 projects (Ministry of Industry and Trade CZ 2019a). However, these resources are time-limited, being linked to the existing programming period 2014-2020. With the onset of the next programming period 20212027, efforts are being made to prepare support so that it is seamlessly linked to the existing programming period, and information on the preparation of conditions for the next programming period implies that $R \& D$ support will again be one of the priority areas of support. Research, development and innovation are conditioned not only by sufficient financial resources, but also by a sufficient number of qualified workers, researchers and innovation implementation experts.

Trends in production (changes of raw material costs, product portfolio and the market situation)

The situation in the chemical industry is also affected by the development of price of raw materials, which, together with the economic growth, are fluctuating (i.e. the price of crude oil in 2010 \$ 79/barrel, in 2012 \$ 112.3/barrel, in 2016 \$ 42.8/barrel and in 2018 \$ 71.5/barrel (OECD, 2019)). Development of prices and export of chemical product have been affected also by releasing of the CZK rate by Czech National Bank in 2017. Based on the requirements of customers there are also changes in product portfolio, it does not concern too much heavy chemistry products, but rather applied chemistry products, mainly in accordance with the commercialization of research and innovation output in form of new products of material chemistry (nanomaterials, biochemical product etc.). Together with the expansion of products, the approach to customers is individualized. Furthermore, it can be stated that the concentration of business groups operating in the chemical industry has been strengthened in the form of several important players providing production mainly in the field of heavy chemistry. On the other hand, the number of entities operating in the chemical industry is growing in connection with the expansion of the products offered and their production (see Table 1). (Choudhury, 2019) 


\section{Labour market situation}

The labour market in $\mathrm{CZ}$ is currently showing a low unemployment rate and a large excess of job offers. As of 31 October 2019, the number of job seekers in CZ was 196,518 while the number of job vacancies was 337,453, the unemployment rate as of that date was $2.7 \%$ (Ministry of Labour and Social Affairs CZ 2019), one of the lowest unemployment rates in Europe.

This situation poses problems for chemical industry companies in recruiting new qualified employees and also puts increased pressure on wage growth. To ensure production, companies use measures such as more active promotion of jobs in $\mathrm{CZ}$ and abroad, recruitment of agency workers and foreign workers, intensive cooperation with secondary schools and universities focused on the training of chemistry specialists, recruitment of less qualified workers and providing them with training or long-term education. It is not only the economic situation and growth, but also the demographic development, with more people leaving the labour market (due to retirement) than those who enter it, that have a significant impact on the situation. In addition, the youngest generation (the so-called Generation Z) has different ideas about getting involved in the work process (demands for greater flexibility in the work process, emphasis on wellbeing, employer's credibility in environmental care and higher wage demands). For more information see (Kostalova and Bednarikova 2019).

\section{Education}

Changes in employee requirements are also expected in the chemical industry as a result of technological changes. In this context, the chemical industry companies are expected to impose requirements on the adequately qualified staff as well as increased training of existing staff in relation to these changes. A greater degree of multidisciplinarity will be required, not only in the natural sciences - chemistry, biology, physics, but also in technical fields, especially information and communication technologies. Requirements for soft skills such as language skills, communication skills, teamwork, etc. will also increase. (Kostalova and Bednarikova 2019) The education of qualified future employees in the chemical industry is mainly provided by secondary vocational schools specializing in chemistry and three universities/faculties (Faculty of Chemical Technology, University of Pardubice, University of Chemistry and Technology Prague and Faculty of Chemistry, Brno University of Technology). At least in universities (with the exception of the Faculty of Chemistry, Brno University of Technology) in recent years, the number of chemistry students has been decreasing (see Table 9). Therefore, chemical companies should turn their attention to the young generation and raise their awareness of the need for qualified workers, job security, and career advancement opportunities (Lostakova et. al. 2018).

Table 9. Development of the number of students at chemical faculties of Czech universities

\begin{tabular}{ccccc}
\hline Year & $\mathbf{2 0 1 5}$ & $\mathbf{2 0 1 6}$ & $\mathbf{2 0 1 7}$ & $\mathbf{2 0 1 8}$ \\
\hline Faculty of Chemical Technology, University of Pardubice & 1,657 & 1,514 & 1,500 & 1,426 \\
University of Chemistry and Technology Prague & 4,358 & 4,189 & 4,155 & 3,917 \\
Faculty of Chemistry Brno, University of Technology & 1,077 & 1,206 & 1,124 & 1,133 \\
Total & 7,092 & 6,909 & 6,779 & 6,476 \\
\hline
\end{tabular}

Source: Brno University of Technology 2019, University of Chemistry and Technology Prague 2019, Faculty of Chemical Technology, University of Pardubice 2019

At all chemical-technology faculties, we can see a strengthening of cooperation with practice, from both sides; on the part of schools with the aim of increasing the interconnection of teaching with practice and offering graduates good employment, on the part of employers with the aim of attracting new qualified workers and thus partially solving the problem in the labour market.

Examples of cooperation with practice from universities and secondary schools as well as examples of massive increase in qualifications of chemical industry employees, e.g. through comprehensive training programmes at company level, in cooperation with universities, etc., can be 
found in available resources (Kostalova and Bednarikova 2019; Association of Chemical Industry 2019; Ministry of Industry and Trade CZ 2018, Ministry of Industry and Trade CZ 2019a)

In the foreseeable future, the challenge is to open up education at these faculties to foreign students, to offer study in English and to stabilize or increase the number of students and thus the offer of graduates for the Czech chemical industry, in addition to excellent language skills.

\section{Recommendation}

Given the above-mentioned situation in the chemical industry, economic development and expected changes, chemical industry companies as well as other entities related to this industry can be recommended to:

- Monitor developments not only on the Czech and European markets, but also on the global market and look for new opportunities;

- Strengthen multidisciplinarity, familiarize themselves with the technological developments represented by Industry 4.0 and introduce innovations to increase productivity, replace routine and unsafe work, technologies to improve monitoring and data analysis to optimize production, reduce energy consumption, use resources more efficiently and increase occupational safety and health and environmental protection;

- Use the available resources to finance research, development and innovation and to introduce technological investments, without limiting themselves to support at national level and rather to try to reach sources of support from the European level more often;

- Emphasize the sustainability of production, focus on and implement measures leading to higher corporate social responsibility, environmental protection, implementation of circular economy principles;

- Invest in education, expand cooperation with secondary schools and universities;

- Expand the offer of branches of study especially at universities in English and thus increase the number of students and graduates.

\section{Conclusions}

The paper analysed the situation of the chemical industry in $\mathrm{CZ}$. The area under assessment was from the producers' point of view CZ NACE 20 and from the product point of view CZ CPA 20 . Like other areas of manufacturing industry in $\mathrm{CZ}$, this area was affected by the economic crisis and subsequently strengthened significantly in the period of economic growth. The development in the chemical industry is now mainly affected by the labour market situation and demographic developments, technological developments and the advent of Industry 4.0, and the expected slowdown in economic growth, which may subsequently lead to the recession of a national or European or global economy, as the case may be. Based on the analysed data, the article presents measures that should help to use open challenges and solve existing problems of the chemical industry in CZ.

\section{References}

Association of Chemical Industry CZ. 2019a. Ročenka 2018 o vývoji chemického průmyslu ČR. Praha: Association of Chemical Industry CZ

Association of Chemical Industry CZ. 2019b. Responsible Care. Available online: https://www.schp.cz/info/responsible-care (accessed on 25 November 2019)

Association of Social Responsibility CZ. 2019. About the Association of Social Responsibility. Available online: http://www.spolecenskaodpovednostfirem.cz/enacsr/\#about-us2 (accessed 25 November 2019)

Brno University of Technology. 2019. Výroční zprávy VUT. Available online: https://www.vutbr.cz/urednideska/vyrocni-zpravy-vut?aid_redir=1 (accessed on 22 November 2019)

Business Leader Forum. 2019. Business Leader Forum. Available online: https://www.csr-online.cz/o-nas/vize-ahistorie/ cz/(accessed on 2 December 2019)

Cefic. 2017. Accelerating Europe towards a sustainable futurehttps://chemistrycan.com/app/uploads/2017/10/SDReport2017.pdf (accessed on 25 November 2019) 
Cefic. 2018. Facts \& Figures of the European chemical industry. Available online: https://cefic.org/app/uploads/2018/12/Cefic_FactsAnd_Figures_2018_Industrial_BROCHURE_TRADE.pdf (accessed on 25 November 2019)

Cefic. 2019. Chemical Trends Report. Available online: https://cefic.org/media-corner/newsroom/eu-chemicalsproduction-grows-1-7-in-q1-2019-compared-to-q4-2018/ (accessed on 1 October 2019)

Choudhury, A. 2019. New Challenges Facing Specialty Chemical Companies I Infiniti Research Unveils the Key Roadblocks to Overcome. Available online: https://www.businesswire.com/news/home/20190715005547/en/New-Challenges-Facing-SpecialtyChemical-Companies-Infiniti (accessed on 14 January 2020)

Czech Statistical Office. 2019a. Ekonomické výsledky průmyslu ČR - 2017. Available online: https://www.czso.cz/csu/czso/ekonomicke-vysledky-prumyslu-cr-2017 (accessed on 26 November 2019)

Czech Statistical Office. 2019b. Veřejná databáze. Available online: https://vdb.czso.cz/vdbvo2/faces/cs/index.jsf?page=vystupobjekt\&pvo=PRU05\&z=T\&f=TABULKA\&skupId=146\&katalog=30835\&pvo=PRU05\&str=v146\&c=v3 3_RP $2011 \# \mathrm{w}=$ (accessed on 27 November 2019)

Czech Statistical Office. 2019c. Zahraniční obchod ČR v národním pojetí - 2005 až 2017. Available online: https://www.czso.cz/csu/czso/zahranicni-obchod-cr-v-narodnim-pojeti (accessed on 26 November 2019)

Deloitte. 2016. Industry 4.0 and the chemicals industry Catalyzing transformation through operations improvement and business growth. Deloitte University Press.

Faculty of Chemical Technology, University of Pardubice. 2019. Výroční zprávy. Available online: https://fcht.upce.cz/fcht/vyrocni-zpravy\# (accessed on 22 November 2019)

Gilchrist, Alasdair. 2016. Industry 4.0 The Industrial Internet of Things. Nonthaburi: Apress.

Kostalova, Jana, and Bednarikova, Marie. 2019. An Analysis of the Chemical Industry Labour Market in the Czech Republic. Chemicke listy. 113, 691-696

Kraus, Josef, and Spicka, Jindrich. 2013. Economic Analysis of Chemical Industry. Chemicke listy: 107, 563-600

Lostakova, Hana, Jelinkova, Martina and Vlckova, Vladimira. 2018. Assessment of employment attractiveness in the Czech chemical industry. Przemysl Chemiczny. 97(11), 1945-1948. https://doi.org/110.15199/62.2018.11.27

Marik, Vladimir. et al. 2016. Průmysl 4.0: výzva pro Českou republiku. Praha: Management Press.

Ministry of Industry and Trade CZ. 2018. Panorama zpracovatelského prưmyslu ČR 2017. Praha: Ministry of Industry and Trade CZ.

Ministry of Industry and Trade CZ. 2019a. Panorama zpracovatelského průmyslu ČR 2018. Praha: Ministry of Industry and Trade CZ.

Ministry of Industry and Trade CZ. 2019b. Panorama-interaktivni-tabulka. Available online: https://www.mpo.cz/cz/panorama-interaktivni-tabulka.html (accessed on 13 November 2019)

Ministry of Industry and Trade CZ. 2019c. Metodika-Panorama zpracovatelského průmyslu ČR 2018. Praha: Ministry of Industry and Trade CZ. Available online: https:/www.mpo.cz/panorama/Metodika_CZ.pdf (accessed on 13 November 2019)

Ministry of Labour and Social Affairs CZ. 2019. Unemployment monthly August. Available online: https://www.mpsv.cz/web/cz/mesicni (accessed on 26 November 2019)

National Observatory of Employment and Training, National Training Fund. 2017. Dopady Průmyslu 4.0 na trh práce v ČR. Available online: http://www.nvf.cz/dopady-prumyslu-4-0-na-trh-prace-v-cr (accessed on 25 November 2019)

OECD. 2019. Crude oil import prices. Available online: https://data.oecd.org/energy/crude-oil-import-prices.htm (accessed on 15 January 2020)

Palisek, Eduard. 2018. Digitalization and Industry 4.0 in the Chemical Industry. Chemicke listy: Vol. 112, 205-206

Tetrevova, Libena, Vavra, Jan, Bednarikova, Marie, Munzarova, Simona, and Kostalova, Jana. 2017. Společenská odpovědnost firem společensky citlivých odvětví. Praha: Grada Publishing

University of Chemistry and Technology Prague. 2019. Výroční zprávy. Available online: https://www.vscht.cz/uredni-deska/zakladni-dokumenty/vyrocni-zpravy (accessed on 22 November 2019)

Wehberg, G. Götz. 2015. Chemicals 4.0 Industry Digitalization form a Business-Strategy Angle. Deloitte.

World Economic Forum. 2018. Why strive for Industry 4.0. Available online: https://www.weforum.org/agenda/2019/01/why-companies-should-strive-for-industry-4-0/ (accessed on 6 October 2019)

Zeleny kruh. 2019. Kdo jsme. Available online: http://www.zelenykruh.cz/o-nas/kdo-jsme (accessed on 2 December 2019). 